\title{
Analysis of tensile properties for conductive textile yarns
}

\section{REZUMAT - ABSTRACT}

\section{Analiza proprietăților tensionale ale firelor textile conductive}

În această lucrare au fost realizate fire conductive prin acoperirea unor fire textile cu o soluție formată din nanoparticule de carbon (CB) cu un diametru mediu de $18 \mathrm{~nm}$, alcool polivinilic (PVA) și apă. Pentru o depunere continuă a stratului conductiv este necesară obținerea unei soluții cu o anumită consistență, motiv pentru care nanoparticulele de carbon se amestecă cu restul ingredientelor, astfel încât stratul conductiv depus pe fir să fie subțire și flexibil, în același timp. Nanoparticulele de carbon au tendința de a se aglomera și, ca urmare, soluția trebuie agitată continuu. Firele utilizate ca suport sunt diferite din punct de vedere al naturii materiei prime, fineței și structurii.

În studiu au fost alese câteva variante de fire pentru a decide care dintre acestea sunt corespunzătoare pentru a obține fire conductive care își păstrează proprietățile inițiale specifice.

Variantele de fire conductive obținute au fost testate din punct de vedere al proprietăților fizice și mecanice (forță de rupere, alungire la rupere), iar din punct de vedere al proprietăților electrice s-a măsurat rezistivitatea electrică. După acoperirea cu stratul conductiv, firele prezintă o rigiditate mai mare, dar pot fi utilizate pentru a obtine materiale textile, cum ar fi țesăturile.

După efectuarea măsurătorilor, se poate concluziona că, firele acoperite cu o soluție conductivă pe bază de nanoparticule de carbon prezintă conductivitate electrică și pot fi utilizate pentru obținerea de țesături textile conductive.

Cuvinte cheie: fire conductive, nanoparticule de carbon, proprietăți mecanice, proprietăți electrice

\section{Analysis of tensile properties for conductive textile yarn}

In this paper conductive yarns were made by coating the yarns with a solution having carbon black nanoparticles (CB) with an average diameter of $18 \mathrm{~nm}$, polyvinyl alcohol (PVA) and water. For a continuous coating deposition it is necessary to obtain a solution of a certain consistency; for this reason, carbon black nanoparticles are mixed with the ingredients so that the resulting film deposited as a thin layer on the yarn to be conductive, and at the same time flexible. The carbon black nanoparticles tend to form aggregates; this is why the solution should be stirred continuously. The yarns used as support are different from the nature, fineness and structure point of view.

Several variants of yarns were chosen in order to decide which ones are appropriate for obtaining conductive yarns that keep their specific initial properties.

The variants of conductive yarns obtained were tested in terms of physical and mechanical properties (tensile strength, elongation), and from the viewpoint of electrical properties, electrical resistivity was measured. After coating the conductive layer, yarns shows greater rigidity, but can be used to obtain textile materials such as woven fabrics.

After performing the measurements, it can be concluded that the yarns coated with a conductive solution based on CB shows electrical conductivity and can be used for obtaining conductive textile fabrics.

Keywords: conductive yarn, carbon black nanoparticles, mechanical properties, electrical properties

\section{INTRODUCTION}

Adding new properties, different from what we were used towards textiles became a major concern of researchers in the field of textile and beyond. These new properties allow the use of textiles in areas that have already been established, but also in other areas, depending on newer properties they own. Conductive textiles represent an attractive area of research, because they can be used for clothing, but also in areas such as medicine, military, heating elements, electronics, sports and leisure etc. [1-10]. Materials and methods for obtaining conductive fabrics are diverse, depending on the domain to be used and the particularities of both the conductive substances and the conductive substrate used. Conductive yarns can be obtained from $100 \%$ conductive fibers or mixed in different proportions, conductive filaments, yarns coated with conductive polymers, metal-plated yarns, or yarns coated with conductive powders such as carbon or metal powders. Textile yarns used as a substrate can be from both natural and chemicals fibers [3, 11-14]. Many of these types of threads are currently obtained on an industrial scale. The films used may be conductive polymer films, such as polypyrrole, polyaniline, polythiophene, polyacetylenes, as well as conductive metals such as silver, copper, gold, platinum, etc. The subsequent conductive yarns produced can be sewn, knitted, woven [16-17]. These may have applications such as antistatic, heating elements, signal transfer, electromagnetic shields materials. Nanoparticles of $C B$ are widely used for applications in conductive fabrics, the reason being that they have conductive properties similar to electrically conductive metals and the 
coating of yarns with $\mathrm{CB}$ nanoparticles retains in a large measure the flexibility and elasticity of the textile material. The methods used often are: screen printing, coating, dyeing and manual deposition [10-14]. In this paper conductive yarns having as base yarns that were coated with a conductive matrix were obtained. The conductive material component of this matrix is CB nanoparticles. In the literature, the conductive yarns have been carried out by various methods, from the polymerization of conductive polymers to electrolytic plating with the metal layer [7, 12, 18]. The method used in this paper is to cover the yarns with conductive substance with $C B$ nanoparticles because it is a method which allows uniform coverage, easiness and not least cheap method.

\section{MATERIAL AND METHOD}

This study deals with comparative analysis of physico-mechanical and electrical properties of several yarns before and after coating them with a conductive layer of carbon based nanoparticles.

The selection of the yarns was carried out after coating them with the CB solutions. Since conductive yarns have particular applications in the field of technical textiles, they should not have the comfort and external presentation properties specific to yarns of natural fibers, and for this reason yarns from fibers such as cotton, wool, bast have not been used in the experiment. Also the cost of chemical yarns used is lower than natural yarns.

The structure and the appearance of the selected yarns are favourable for coating a bigger amount of conductive solution in order to obtain significant values for the electrical resistivity.

The yarns were conditioned under standard atmosphere of $65 \% \pm 2 \% \mathrm{RH}$ and $20^{\circ} \mathrm{C} \pm 2{ }^{\circ} \mathrm{C}$ temperature for 24 hours. The under test yarns $(\mathrm{Y})$ were chosen to have approximately the same count, but from different raw materials and with different structures. In table 1 the yarns analysed are presented.

These yarns were coated with an electrically conductive layer deposited by immersing the yarn in a solution made according to the recipe: $10 \%$ nanoparticles of carbon black, $40 \%$ PVA, $50 \%$ water. Tensile properties of the yarns have been tested according to ISO 2062, using constant rate of specimen extension (CRE) tensile testers on a Tinius Olsen H5kT. The gauge length was $250 \mathrm{~mm}$ and the tensile testing speed was adjusted so that yarn break is reached in
$20 \pm 3$ s. The variants of coated yarns (CY) were analyzed in terms of mechanical and electrical properties. The mechanical properties analyzed were: breaking strength, coefficient of variation of strength, breaking elongation, coefficient of variation of elongation, breaking tenacity, coefficient of variation of tenacity. The breaking strength is one of the basic features of the yarns because it influences the behaviour of yarns in processing (for weaving preparation, weaving, knitting), thus establishing the technological parameters of the machines and their productivity. Coefficient of variation of breaking force influences the behaviour of yarns in the manufacturing process causing the machine's efficiency and product quality trough the number of nodes. Elongation at break is a characteristic of the yarns which influence their behaviour in the technological processes and the characteristics of wearability of the product. The tenacity of the yarns was determined to compare them, because they have approximately equal count. The electrical properties of the coated yarns were tested with TTI 1705 True RMS Programmable multimeter.

The resistance of a yarn, $R[\Omega]$, with the length $I$, can be calculated with the following formula (considering annular cross-section):

$$
R=\frac{I \cdot \rho}{A}=\frac{4 \cdot I \cdot \rho}{\pi \cdot d^{2}}
$$

where $R$ is the resistance of the conductor [ $\Omega]$, $/$ is the length of the conductor [m], $\rho$ is the electrical resistivity of a conductor $[\Omega \cdot \mathrm{m}], A$ is the cross-sectional area $\left[\mathrm{m}^{2}\right], d$ is the nominal diameter of the yarn [mm] [19].

Electric resistivity, $\rho[\Omega \cdot \mathrm{m}]$, is a measure of how strongly the conductive yarn opposes electric current. A low resistivity indicates a yarn that allows the movement of electrical charge [18].

$$
\rho=\frac{R \cdot A}{l}=\frac{\pi \cdot d^{2} \cdot R}{4 \cdot l}
$$

Resistivity is expressed as the resistance per unit length, usually measured in $\Omega \cdot \mathrm{cm}$. The textile fibers and yarns are irregular, their size varying. The thickness of the conductive solution is not uniform and the contact with the electrodes in the different points of measurement cannot be the same. In this case, the resistance of a fiber/yarn is proportional to the length of the material. However, the conductivity of the material is characterized as electrical resistance with

\begin{tabular}{|c|c|c|c|c|c|}
\hline & $\begin{array}{c}\text { Fancy yarn } \\
\text { (Y1) }\end{array}$ & $\begin{array}{l}\text { Worsted spun } \\
\text { yarn } \\
\text { (Y2) }\end{array}$ & $\begin{array}{c}\text { Textured yarn } \\
\text { (Y3) }\end{array}$ & $\begin{array}{l}\text { Worsted spun } \\
\text { yarn } \\
\text { (Y4) }\end{array}$ & $\begin{array}{c}\text { Two-ply yarn } \\
\text { (Y5) }\end{array}$ \\
\hline Count of yarn, [tex] & 74 & 26 & $16.7 \times 2$ & 40 & $2 \times 7.8 \times 2$ \\
\hline $\begin{array}{l}\text { Yarn composition, } \\
\text { [\%] }\end{array}$ & $\begin{array}{c}\text { Polyester/acrylic } \\
40 / 60\end{array}$ & $\begin{array}{c}\text { Polyester/viscose } \\
60 / 40 \\
\end{array}$ & $\begin{array}{c}\text { Polyester } \\
100 \%\end{array}$ & $\begin{array}{c}\text { Acrylic } \\
100 \%\end{array}$ & $\begin{array}{c}\text { Polyamide } \\
100 \%\end{array}$ \\
\hline Yarn structure & $\begin{array}{l}\text { Spiral fancy yarn from PET } \\
\text { textured yarn and spun } \\
\text { yarns from acrylic fibers }\end{array}$ & $\begin{array}{l}\text { Worsted spun } \\
\text { yarn }\end{array}$ & $\begin{array}{l}\text { Textured yarn, } \\
\text { PET } 167 \text { f32×2 }\end{array}$ & $\begin{array}{l}\text { Worsted spun } \\
\text { yarn }\end{array}$ & $\begin{array}{l}\text { Two-ply yarn, } \\
\text { PA6 } 2 \times 7 \\
\text { f18×2 }\end{array}$ \\
\hline
\end{tabular}

Table 1 
the distance between the electrodes used for the resistance measurements. The two probe method was used to test the resistance of conductive yarns. Resistance of samples was measured with the distance between the ends of the specimen by $0.1 \mathrm{~m}$. The diameter was determined under the microscope by image analysis method using a magnification of 42×. 10 measurements were performed in 10 different positions along the length of the yarn. The yarn was tensioned with a force of $0.05 \mathrm{cN} / \mathrm{tex}$.

\section{RESULTS AND DISCUSSION}

Regarding the electrical properties, the electrical resistance was measured and the resistivity of the coated yarns was calculated, according to the diameter of the yarn. In table 2 are presented the mechanical properties for the tested yarns, before and after coating, and table 3 indicates the electrical properties of the yarns. the fancy yarn (CY1), breaking elongation increase by $27.46 \%$ due to its structure (spiral fancy yarn). The breaking elongation for the textured yarn CY5 almost doubled, and the elongation for the simple textured yarn (CY3) not changed very much.

- Coefficient of variation for breaking elongation increased for all variants of yarns due to a less uniform deposit of the conductive layer onto yarns.

- The effect of coating has reduced the values for tenacity of yarns at least twice, although the breaking strength of the coated yarns has increased. The decrease is justified by a higher increase of the weight of the coated yarns in relation to a smaller increase of their strength.

- Coefficient of variation of the tenacity increased for all variants of coated yarns due to the fact that the conductive layer was deposited less evenly.

For all the coated yarns, the values for electrical resistivity are between 0.09 and $0.3094 \Omega \cdot \mathrm{m}$.

Table 2

\begin{tabular}{|l|c|c|c|c|c|c|c|c|c|c|}
\hline \multirow{2}{*}{\multicolumn{1}{|c|}{ Tensile properties }} & \multicolumn{10}{c|}{ Variants of yarns } \\
\cline { 2 - 11 } & Y1 & CY1 & Y2 & CY2 & Y3 & CY3 & Y4 & CY4 & Y5 & CY5 \\
\hline Breaking strength, [cN] & 856 & 1002 & 318.8 & 389.8 & 1006 & 929 & 382.9 & 458.5 & 1507 & 1224 \\
\hline Coefficient of variation of strength, [\%] & 7.04 & 8.79 & 8.34 & 9.87 & 2.24 & 4.51 & 7.72 & 9.82 & 2.01 & 3.98 \\
\hline Breaking elongation, [\%] & 22.72 & 28.96 & 13 & 10.15 & 35.64 & 35.5 & 11.01 & 7.02 & 29.25 & 55.8 \\
\hline Coefficient of variation of elongation, [\%] & 4.994 & 8.27 & 7.36 & 18.42 & 5.77 & 6.58 & 10.44 & 36.63 & 4.65 & 9.49 \\
\hline Breaking tenacity, [cN/tex] & 11.57 & 2.17 & 12.31 & 4.41 & 28.77 & 7.05 & 9.70 & 2.71 & 46.19 & 7.96 \\
\hline Coefficient of variation of tenacity, [\%] & 5.07 & 11.50 & 3.55 & 12.94 & 1.86 & 14.17 & 8.70 & 26.76 & 2.66 & 24.30 \\
\hline
\end{tabular}

Table 3

\begin{tabular}{|l|c|c|c|c|c|}
\hline \multirow{2}{*}{$\begin{array}{c}\text { Electrical } \\
\text { properties }\end{array}$} & \multicolumn{5}{|c|}{ Variants of yarns } \\
\cline { 2 - 6 } & CY1 & CY2 & CY3 & CY4 & CY5 \\
\hline $\begin{array}{l}\text { Electrical } \\
\text { resistance, [k } \Omega]\end{array}$ & 36.384 & 563.4 & 75.5 & 0.2682 & 0.1422 \\
\hline $\begin{array}{l}\text { Diameter of } \\
\text { yarn, [mm] }\end{array}$ & 0.8352 & 0.2645 & 0.3897 & 0.5845 & 0.4256 \\
\hline $\begin{array}{l}\text { Electric } \\
\text { resistivity, } \Omega \cdot \mathrm{m}]\end{array}$ & 0.1992 & 0.3094 & 0.0900 & 0.2365 & 0.2559 \\
\hline
\end{tabular}

Analyzing the data of the table shows the following: - The breaking strength of coated yarns increases by approx. $20 \%$ in the case of yarns from staple fibers, respectively CY1, CY2 and CY4. In the case of the yarns from continuous fibers (CY3 and CY5), their tensile strength decreases because the strength of the fibers from coated yarns is not completely utilized in yarn's strength. This decrease is smaller for the CY3 yarn, which is a simple textured yarn versus CY5 yarn which is a two-ply yarn.

- Coefficient of variation of breaking force increases for all coated yarns analyzed. The increase is by $24.86 \%$ for $\mathrm{CY} 1,18.34 \%$ for $\mathrm{CY} 2$ and $27.2 \%$ for $\mathrm{CY} 4$, while for the yarns from continuous fibers is by approximately $100 \%$.

- Breaking elongation of the spun fibers (CY2 and CY4) decreases by about $20 \%$ after coating, while for
Analyzing the electrical resistivity is found that the yarns coated with the conductive layer can be classified as semiconductors, semiconductors have resistivity between $10^{-4} \div 10^{10} \Omega \cdot \mathrm{m}$ [20]. In addition, as a result of resistivity values, these conductive yarns could be used to obtain products for electromagnetic shielding (EMI shielding).

For further applications, such as woven or knitted fabrics, a flexible polymer should be coated on the conductive yarns obtained in order to maintain the integrity of the conductive layer. Therefore, the bending properties of the conductive yarns were not taken into consideration. The resulting fabrics obtained using the conductive yarns can be tested for bending and shearing properties.

\section{CONCLUSIONS}

All five yarns coated with the solution based on $C B$ nanoparticles shows conductivity. The values obtained justify their use as components in a conductive fabric or a knitted fabric that can be used for electromagnetic shielding. Regarding the mechanical characteristics, the yarns used have higher, or about the same values for the breaking strength comparative with the values obtained before coating with the conductive layer, and lower values of elongation, but not significant, so there is certainty that they will behave properly in further technological processes. The coating mixture allow obtaining of conductive 
materials using a method which can be easily reproduced at industrial level, the next step is weaving/ knitting these conductive yarns to see if the conductive layer stay onto the yarns and does not create discontinuities.

The conductivity of the analysed yarns is transferred in the subsequent textile product electrical properties. However, in this paper only the manufacturing of the conductive yarns was studied. The electrical properties of a textile product obtained with these yarns depend on various factors: the percentage of conductive yarns, the fabric structure, the density of yarns, and the thickness of the fabric. Future researches will be conducted to produce several textile fabrics using conductive yarns, testing electrical and tensile properties and predict their applications.

\section{BIBLIOGRAPHY}

[1] Dulgheriu, I., Ionescu, I., Ionesi, D., Dragomir, A. Evaluation and calculation model for heat transfer equilibrium through clothing articles, In: Industria Textilă, 66, nr. 2, 2015, p. 59.

[2] Dulgheriu, I., Avădanei, M., Cozmanciuc, C. Research concerning the heat-sealed treatment parameters influence on the main characteristics of a doubled ensemble, In: Tekstilve Konfeksiyon, 24, nr. 4, 2014, p. 380.

[3] Ramachandran, T., Vigneswaran, C. Design and development of copper core conductive fabrics for smart textiles, In: Journal of Industrial Textiles, 39, nr. 1, 2009, p. 81.

[4] Carpi, F., Derossi, D. Electroactive polymer-based devices for e-textiles in biomedicine, IEEE Trans. In: Informations Technol. Biomed., 9(3), 2005, p. 259.

[5] Post, E. R. et al. E-Broidery: Design and fabrication of textile-based computing, In: IBM Systems Journal, 39(3\&4), 2000 , p. 840.

[6] Loghin, C., Nicolaiov, P., Ionescu, I., Dulgheriu, I. Thermal characterization of coated fabrics, In: Buletinul AGIR, nr. 1, 2013, p. 173.

[7] Hakansson, E. et al. Characterization of conducting polymer coated synthetic fabrics for heat generation, In: Synthetic Metals, 144, 2004, p. 21-28.

[8] Ionesi, D., Ciobanu, L. Evaluation of tensile behaviour of raw materials used for composites reinforcement, In: International Symposium in Knitting and Apparel - ISKA 2013 lasi, June 21-22, 2013, p. 62.

[9] Ionesi, D., Dumitraș, C., Ciobanu, L., Vîrcan, A. Analysis of low velocity impact behaviour of aramid-linen fibre reinforced composites using Taguchi method, In: Journal of Optoelectronics and Advanced Materials, nr. 5-6, 2012, p. 544.

[10] Gupta K.K. et al. Carbon black/polyurethane nanocomposite-coated fabric for microwave attenuation in $X$ \& Ku-band $(8-18 \mathrm{GHz})$ frequency range, In: Journal of Industrial Textiles, available on jit.sagepub.com.

[11] Panhuis, M. et al. Conducting textiles from single-walled carbon nanotubes, In: Synthetic Metals, 157, nr. 8-9, 2007, p. 358.

[12] Fugetsu, B. et al. The production of soft, durable and electrically conductive polyester multifilament yarns by dye-printing them with carbon nanotubes, In: Carbon, 47, nr. 2, 2009, p. 527.

[13] Xue, P. et al. Electrically conductive yarns based on PVA/Carbon nanotubes, In: Composite Structures, 78, nr. 2, 2007, p. 271.

[14] Hasan, M.M.B., Diestel, O., Cherif, C. Electro-mechanical properties of friction spun conductive hybrid yarns made of carbon filaments for composites, In: Textile Research Journal, 81(15), 2013, p. 1603.

[15] Loghin, C., Ursache, M., Ionescu, I. Experimental research on the sewability of ferromagnetic micro-wires, In:Tekstilve Konfeksiyon, 20, nr. 4, 2010, p. 373.

[16] Dhavan, A. at al., Woven fabric-based electrical circuits: Part II: Yarn and fabric structures to reduce crosstalk noise in woven fabric-based circuits, In: Textile Research Journal, 74(11), 2004, p. 955.

[17] Orth, M. Defining flexibility and sewability in conductive yarns, In: Proceedings of the Materials Research Society Symposium, Boston, 736, 2003, 47.

[18] Ding, J. et al. Electroless synthesis of nano-structured gold particles using conducting polymer nanoparticles, In: Synthetic Metals, 158, nr. 14, 2008, p. 585.

[19] Morton, W.E; Hearle, J.W.S. Physical properties of textile fibres, ISBN 1845692209, Woodhead Publishing, London, 2008.

[20] Mattila, H.R. Intelligent textiles and clothing, ISBN 184569005 2, ISBN-13: 9781845690052 Woodhead Publishing Series in Textiles No. 54, 2006, p. 217.

\section{Authors:}

\section{LILIANA BUHU, DANIELA NEGRU, EMIL CONSTANTIN LOGHIN and ADRIAN BUHU}

"Gheorghe Asachi" Technical University of lași, Faculty of Textile, Leather and Industrial Management

\section{Corresponding author:}

DANIELA NEGRU

e-mail: dnegru@tex.tuiasi.ro 